\title{
Ecological Civilization Demonstration Zone, Air Pollution Reduction, and Political Promotion Tournament in China: Empirical Evidence from a Quasi-Natural Experiment
}

\author{
Haijie Wang ${ }^{1}$, Yong Geng ${ }^{2}{ }^{(D}$, Jingxue Zhang ${ }^{1} \mathbb{D}$, Xiqiang Xia ${ }^{1}\left(\mathbb{D}\right.$ and Yanchao Feng ${ }^{1, *} \mathbb{C}$ \\ 1 Business School, Zhengzhou University, Zhengzhou 450001, China; whj@zzu.edu.cn (H.W.); \\ m15803900638@163.com (J.Z.); xqxia@zzu.edu.cn (X.X.) \\ 2 School of Environmental Science and Engineering, Shanghai Jiao Tong University, Shanghai 200240, China; \\ ygeng@sjtu.edu.cn \\ * Correspondence: m15002182995@163.com
}

check for

updates

Citation: Wang, H.; Geng, Y.; Zhang, J.; Xia, X.; Feng, Y. Ecological Civilization Demonstration Zone, Air Pollution Reduction, and Political Promotion Tournament in China: Empirical Evidence from a Quasi-Natural Experiment. Int. J. Environ. Res. Public Health 2021, 18, 11880. https:// doi.org/10.3390/ijerph182211880

Academic Editor: Paul B. Tchounwou

Received: 13 September 2021 Accepted: 11 November 2021 Published: 12 November 2021

Publisher's Note: MDPI stays neutral with regard to jurisdictional claims in published maps and institutional affiliations.

Copyright: (c) 2021 by the authors. Licensee MDPI, Basel, Switzerland. This article is an open access article distributed under the terms and conditions of the Creative Commons Attribution (CC BY) license (https:/ / creativecommons.org/licenses/by/ $4.0 /)$.

\begin{abstract}
Using the ecological civilization demonstration zone as a quasi-natural experiment, this study has explored the effect of it on air pollution in China by employing the difference-in-differences model and the spatial difference-in-differences model, and further tested the political promotion tournament in China by employing the binary logit model. The results show that the ecological civilization demonstration zone has basically and effectively reduced air pollution, except for carbon monoxide and ozone. In addition, the spatial spillover effects of the ecological civilization demonstration zone on air pollution are not only basically supported among the treated cities, but also extremely established in the untreated cities neighboring the treated cities. Furthermore, no clear evidence supports the establishment of the political promotion tournament in China, while local cadres tend to cope with the assessment of higher officials passively rather than actively. Overall, this study sheds light on the coordination of economic development and ecological civilization from the perspective of the career concerns of local cadres.
\end{abstract}

Keywords: ecological civilization demonstration zone; air pollution reduction; political promotion tournament; quasi-natural experiment; spatial difference-in-differences

\section{Introduction}

As the undesirable by-product of industrialization and urbanization in China, environmental pollution not only hurts the human health of residents, but also threatens the sustainable development of biological systems [1]. In particular, air pollution has caused enough attention globally for its characteristic of spatial spillover effect [2]. Based on the data delivered by China's Ecological Environment Status Bulletin in 2018, 64.2\% of 338 prefecture-level and above cities exceeded air quality standards. Against this background, the joint governance of air pollution has become a consensus for policymakers, scholars, and the public [3], which forms the initial motivation of this study.

In the stage of shifting from high growth to high quality development, ecological civilization becomes a crucial issue in the new era [4]. As one representative nation of the centralized powers, the Chinese central government has a dominant role in environmental protection, where the top-down political promotion tournament system forced local cadres to focus on economic performance and infrastructure investment, while the governance of environmental pollution has been neglected in the past [5]. Fortunately, this situation began to change since the implementation of the 11th Five-Year Plan in 2006, with environmental performance incorporating to the promotion mechanism of local cadres [6]. In particular, "ecological civilization demonstration zones" (ECDZ), which are different from the prior economic zones, environmental protection zones, or free trade zones, become a breakthrough point $[7,8]$.

Nevertheless, due to inconsistent environmental performance assessment standards across different regions, highly polluting enterprises tend to move from areas with strict 
control to areas with less control, which reduces the whole effect of environmental regulation and is detrimental to ecological protection [9]. Even so, air quality has been improved nationwide in recent years [10]. For instance, according to the data of China's Ministry of Ecology and Environment, the $\mathrm{PM}_{2.5}$ non-compliance of prefecture-level and above cities in 2020 has decreased by $28.8 \%$ compared with 2015 . However, whether and how ECDZ affects air pollution in China still remain as a black box, which leaves an opportunity for this study.

Due to the advantage of identifying the policy effect of quasi-natural experiments in econometric analysis, the difference-in-differences (DID) model has been widely used in policy evaluation [11]. Hence, in order to initially verify the effect of ECDZ on air pollution, this study attempts to set ECDZ as a multi-phrase quasi-natural experiment, and employ the DID model as the benchmark empirical method [11]. Furthermore, in order to identify the potential existence of spatial spillover effect, the spatial difference-in-differences (SDID) is also employed, especially in regional/spatial econometric studies [12]. Last but not least, in order to test the establishment of political promotion tournament in China, this study has established a comprehensive framework to investigate the impact of economic growth rate and air pollution reduction on political promotion by employing the binary logit model [13].

The marginal contributions of this study can be drawn from two aspects. Theoretically, the current estimates of the effects of air pollution are mainly concentrated in the economic and medical field, while few studies focused on the political field with the consideration of economic growth by establishing a comprehensive framework under the background of the political promotion tournament in China. Hence, this study takes advantage of the opportunity and has great theoretical significance for institutional economics and political economics, especially for the emerging countries with similar situations. In practice, the current discussion on ecological civilization mainly focuses on its measurement and driving forces, while no study has comprehensively explored the environmental impact of ECDZ in China, especially with the consideration of heterogeneous pollutants and spatial spillover effects. Therefore, this study has great practical significance for construction and optimization of ECDZ in China, and also has significant international meanings for other emerging powers.

We organize the rest of this study as follows. Section 2 gives a brief description of institutional background. Section 3 describes the data and method. Section 4 presents our results and proposes discussion. Section 5 concludes the main findings, delivers the policy implications, and points out the research prospects.

\section{A Brief Description of Institutional Background}

As a fundamental part of the reform, China's central authority began to be decentralized to local governments in 1984, and this led to fierce fiscal competition among regional governments with the incentives of economic growth and political promotion [14]. On the one hand, although local governments share tax revenues with the central government, they are entirely responsible for local spending, while fiscal expenditure often exceeds revenue; thus off-budget revenue becomes the other channel to maintain high-speed economic growth [15]. On the other hand, to be recognized by the superior officials and gain political promotion under the top-down political system, local cadres tend to focus on the short-term goal of economic growth, which can be intuitively and quickly revealed by GDP and its growth [16].

However, since economic growth was placed in the primary position and the competition among local cadres was based on the economic performance, local governments tend to generally enforce environmental regulations with low standards to obtain mobility, which leads to extensive development at the expense of environmental pollution [17]. In particular, due to the characteristics of spatial spillover effect and regional heterogeneity for air pollution, the win of "blue sky defense war" still has a long way to go [18]. Against this background, ecological civilization, a new concept of green development, gradually gains the attention of policymakers and scholars [19].

As a philosophical topic and cultural theory, ecological civilization focused on balancing the relationship between humans and nature [20]. However, due to the limited space for science and technology discourse, ecological civilization has not been thoroughly 
conducted in practice until the administrative announcement of building it in the 17th Party Congress in 2007 [21]. Then, the construction of ecological civilization was incorporated into the overall layout of "Five-in-One" in the 18th Party Congress in 2012, and the concept of "beautiful China" highlighted the importance of accelerating the implementation of ecological civilization in the 19th Party Congress in 2017 [22]. Thus, in order to achieve the win-win of saving energy and reducing pollution, ecological civilization was gradually elevated to a more prominent position, which is also expected to be the endogenous driving force of green, sustainable, and high-quality development [23].

Against this background, to promote the construction of ecological civilization, the National Development and Reform Commission and other six ministries issued the "ecological civilization demonstration zone construction program (pilot)" in 2013, and then the first batch of ecological civilization demonstration zones (ECDZ) was officially designated in 2014, followed by the second batch of ECDZ in 2015 [24]. In particular, although the pilot areas of ECDZ formulated their own plans, respectively, the goal of cleaner production and green development is to some extent unified, which forms an ideal quasi-natural experiment to explore the effects of ECDZ on air pollution, and an opportunity to test the establishment of a political promotion tournament in China by investigating the effects of economic growth and air pollution reduction on political promotion.

To vividly illustrate two different types of promotion logic, we draw Figure 1 as follows. In the past, the traditional guiding ideology of a political promotion tournament was "only GDP", that is, local cadres with better economic performance are more likely to be promoted while the opposite will face a lower promotion probability [16-18]. Since the announcement of ecological civilization, a new model of political promotion tournament was proposed and air pollution reduction (or environmental performance) had priority over economic growth, that is, only those who meet the environmental criteria firstly and achieve rapid economic growth simultaneously are more likely to be promoted [19-23]. Against this institutional reform, local cadres will have enough impetus in developing the economy and protecting the environment at the same time to achieve the win-win of an economy-environment balance.

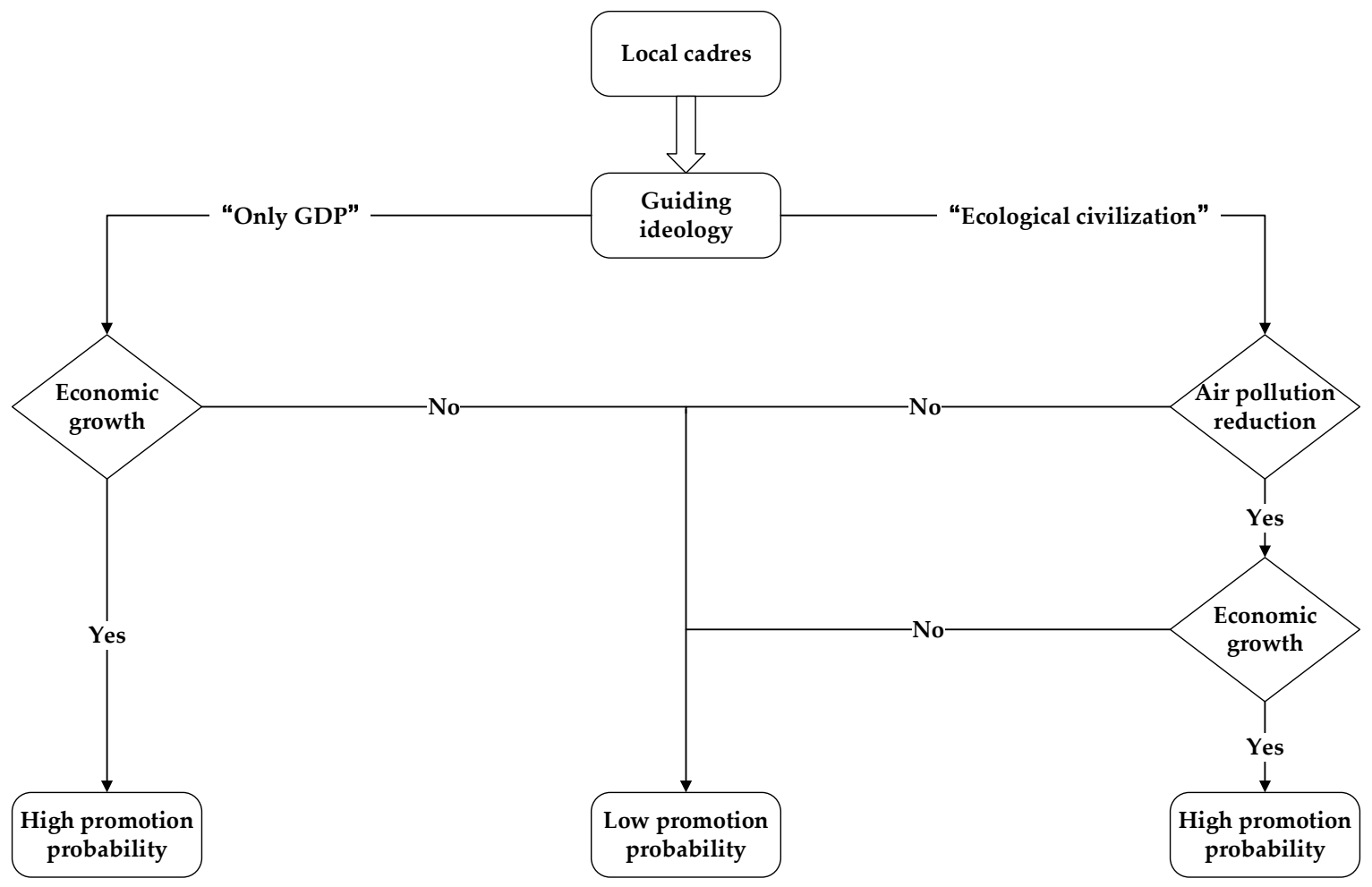

Figure 1. Two types of promotion logic in China. 


\section{Data and Methods}

\subsection{Data Sources}

This study obtained the data from several sources. First, the air pollution data at the city level came from the Chinese Research Data Services (CNRDS) platform, which collects daily data on AQI, which was calculated by the concentrations of six air pollutants, namely, fine particulate matter with a diameter of 2.5 millionths of a meter or less $\left(\mathrm{PM}_{2.5}\right)$, coarse particulate matter with a diameter of 10 millionths of a meter or less $\left(\mathrm{PM}_{10}\right)$, sulfur dioxide $\left(\mathrm{SO}_{2}\right)$, carbon monoxide $(\mathrm{CO})$, nitrogen dioxide $\left(\mathrm{NO}_{2}\right)$, and ozone $\left(\mathrm{O}_{3}\right)$. Second, the biographical and promotional information of local cadres was mainly collected from two official websites, namely xinhuanet.com (accessed on 20 October 2020) and people.com (accessed on 21 October 2020). Third, the list of pilot cities where ECDZ were located was mainly sourced from the website of the National Development and Reform Commission in China. Fourth, the socioeconomic data were collected from the China City Statistic Yearbook and the China Urban Construction Statistic Yearbook. In particular, this study has deleted several cities, namely, the four municipalities directly under the central government (Beijing, Tianjin, Shanghai, and Chongqing), the prefecture level cities with severe data loss and administrative changes (Lhasa, Haidong, Turpan, Laiwu, and so on), and dozens of national autonomous prefecture cities, and eventually formed panel data including 280 cities from 2014 to 2019 as the studying samples.

\subsection{Variables Measurement}

The descriptive statistics of variables are reported in Table 1. In particular, the variables of this study have divided into two parts: Panel A and Panel B, which was employed to analyze the effects of ECDZ on air pollution and the effects of economic growth and air pollution reduction on political promotion, respectively.

Table 1. Descriptive statistics.

\begin{tabular}{|c|c|c|c|c|c|c|c|}
\hline Panel & Variables & Unit & Count & Mean & S.D & Min & Max \\
\hline \multirow{14}{*}{ A } & AQI & - & 1680 & 80.208 & 22.978 & 18.000 & 230.000 \\
\hline & $\mathrm{PM}_{2.5}$ & $\mathrm{mg} / \mathrm{m}^{3}$ & 1680 & 46.770 & 18.857 & 9.000 & 150.000 \\
\hline & $\mathrm{PM}_{10}$ & $\mathrm{mg} / \mathrm{m}^{3}$ & 1680 & 81.776 & 32.507 & 18.000 & 371.000 \\
\hline & $\mathrm{SO}_{2}$ & $\mathrm{mg} / \mathrm{m}^{3}$ & 1680 & 21.841 & 17.011 & 2.000 & 185.000 \\
\hline & $\mathrm{CO}$ & $\mathrm{mg} / \mathrm{m}^{3}$ & 1680 & 0.923 & 0.431 & 0.000 & 7.000 \\
\hline & $\mathrm{NO}_{2}$ & $\mathrm{mg} / \mathrm{m}^{3}$ & 1680 & 30.890 & 10.240 & 5.000 & 66.000 \\
\hline & $\mathrm{O}_{3}$ & $\mathrm{mg} / \mathrm{m}^{3}$ & 1680 & 87.841 & 15.842 & 23.000 & 160.000 \\
\hline & DID & - & 1680 & 0.339 & 0.474 & 0.000 & 1.000 \\
\hline & $\ln P G D P$ & $10^{4}$ Yuan & 1680 & 4.607 & 2.537 & 0.283 & 28.991 \\
\hline & $(\ln P G D P)^{\wedge} 2$ & $10^{4}$ Yuan & 1680 & 27.659 & 39.268 & 0.080 & 840.489 \\
\hline & PD & Persons $/ \mathrm{km}^{2}$ & 1680 & 555.017 & 515.626 & 12.460 & 6814.815 \\
\hline & SI & $\%$ & 1680 & 44.839 & 10.185 & 11.040 & 75.970 \\
\hline & TI & $\%$ & 1680 & 45.032 & 10.400 & 19.770 & 79.710 \\
\hline & FP & $\%$ & 1680 & 12.051 & 10.522 & -13.660 & 92.650 \\
\hline \multirow{14}{*}{ B } & PPT & - & 1400 & 0.214 & 0.410 & 0.000 & 1.000 \\
\hline & GDP & $\%$ & 1400 & 7.017 & 7.959 & -38.663 & 136.163 \\
\hline & DAQI & - & 1400 & 3.417 & 15.300 & -64.580 & 146.580 \\
\hline & $\mathrm{DPM}_{2.5}$ & $\mathrm{mg} / \mathrm{m}^{3}$ & 1400 & 7.760 & 21.096 & -70.580 & 276.000 \\
\hline & $\mathrm{DPM}_{10}$ & $\mathrm{mg} / \mathrm{m}^{3}$ & 1400 & 4.905 & 9.980 & -30.250 & 128.170 \\
\hline & $\mathrm{DSO}_{2}$ & $\mathrm{mg} / \mathrm{m}^{3}$ & 1400 & 4.285 & 12.481 & -52.580 & 92.250 \\
\hline & $\mathrm{DCO}$ & $\mathrm{mg} / \mathrm{m}^{3}$ & 1400 & -0.011 & 0.365 & -1.840 & 5.770 \\
\hline & $\mathrm{DNO}_{2}$ & $\mathrm{mg} / \mathrm{m}^{3}$ & 1400 & 1.115 & 5.687 & -24.500 & 39.250 \\
\hline & $\mathrm{DO}_{3}$ & $\mathrm{mg} / \mathrm{m}^{3}$ & 1400 & -3.283 & 11.828 & -68.000 & 69.250 \\
\hline & AGE & Year & 1400 & 52.075 & 3.245 & 40.000 & 63.000 \\
\hline & EDUCATION & - & 1400 & 0.779 & 0.415 & 0.000 & 1.000 \\
\hline & GENTER & - & 1400 & 0.943 & 0.232 & 0.000 & 1.000 \\
\hline & TENURE $_{1}$ & - & 1400 & 0.356 & 0.479 & 0.000 & 1.000 \\
\hline & TENURE $_{5}$ & - & 1400 & 0.047 & 0.212 & 0.000 & 1.000 \\
\hline
\end{tabular}

Notes: DAQI, $\mathrm{DPM}_{2.5}, \mathrm{DPM}_{10}, \mathrm{DSO}_{2}, \mathrm{DCO}, \mathrm{DNO}_{2}$, and $\mathrm{DO}_{3}$ denotes the first-order difference of $\mathrm{AQI}, \mathrm{PM}, 5$ $\mathrm{PM}_{10}, \mathrm{SO}_{2}, \mathrm{CO}, \mathrm{NO}_{2}$, and $\mathrm{O}_{3}$, respectively.

In Panel $\mathrm{A}$, the annual average value of $\mathrm{AQI}(\mathrm{AQI})$ and the concentrations of six air pollutants (i.e., $\mathrm{PM}_{2.5}, \mathrm{PM}_{10}, \mathrm{SO}_{2}, \mathrm{CO}, \mathrm{NO}_{2}$, and $\mathrm{O}_{3}$ ) are adopted to act as the proxy of 
the dependent variables; DID, a dummy variable, denotes the core explanatory variable, which equals to 1 after the city owns the title of ECDZ, and otherwise 0 ; in addition, several control variables are introduced into the research framework to control for the characteristics of each city, including the natural logarithmic of per capita gross domestic product $(\ln P G D P)$ and its quadratic term $\left((\ln P G D P)^{\wedge} 2\right)$ to test the establishment of the Environmental Kuznets Curve, population density (PD) measured by the share of total population to municipal area, the share of secondary industry to GDP (SI), the share of third industry to GDP (TI), and financial pressure (FP) measured by the share of the difference between fiscal expenditure and fiscal revenue to GDP.

In panel B, political promotion (PP), a dummy variable, is adopted to act as the proxy of the dependent variables, which equals to 1 if the cadre is promoted to a higher rank, otherwise 0; economic growth rate with one year lag (EGR) and air pollution reduction (DAQI, $\mathrm{DPM}_{2.5}, \mathrm{DPM}_{10}, \mathrm{DSO}_{2}, \mathrm{DCO}, \mathrm{DNO}_{2}$, and $\mathrm{DO}_{3}$ ) are employed to act as the proxy of the core explanatory variables; in addition, several control variables are employed to control for the characteristics of each cadre, including age (AGE), education (EDUCATION), gender (GENDER), and tenure (TENURE 1 and TENURE ${ }_{5}$ ). Specifically, education (EDUCATION) is a dummy variable, which equals to 1 if the cadre has a doctorate degree, and 0 otherwise; gender (GENDER) is also a dummy variable, which equals to 1 if the cadre is a male, and 0 otherwise. Moreover, since the tenure of cadres is no more than 5 years, this study employs two dummy variables, namely TENURE ${ }_{1}$ and TENURE ${ }_{5}$, which equal to 1 if it is the first year or the last year of the tenure, and 0 otherwise.

\subsection{Model Specification}

Treating the establishment of ECDZ as a quasi-natural experiment, we first use the difference-in-differences (DID) model to evaluate the effects of it on air pollution in China [11], and construct the following basic model.

$$
Y_{i t}=\beta_{0}+\beta_{1} \times \operatorname{DID}_{i t}+\beta_{2} \times X_{i t}+\mu_{t}+\varepsilon_{i t}
$$

where $Y_{i t}$ represents the air pollution at city $i$ in year $t, \beta_{0}$ represents the constant term, DID $_{i t}$ represents the core explanatory variable, $\beta_{1}$ represents the coefficient of DID $D_{i t}, X_{i t}$ represents a vector of control variables, $\beta_{2}$ represents the coefficients of $X_{i t}, \mu_{t}$ represents the time fixed effect, and $\varepsilon_{\text {it }}$ represents the random error term.

The DID model based on a quasi-natural experiment can to some extent cause the endogeneity problem. However, the spatial spillover effects of air pollution cause the failing at obtaining consistent estimators under the traditional DID model. Fortunately, with the spatial lag terms incorporating into the traditional DID model, the spatial difference-indifferences (SDID) model can control such spatial spillover effects. In particular, considering the advantage of the SLX (i.e., a spatial lag of the independent variables) model in calculating local spillover effects rather than global spillover effects, this study has constructed the SDID model with the assumption of the SLX model [12], which is constructed as follows:

$$
\mathrm{Y}_{\mathrm{it}}=\beta_{0}+\beta_{1} \times \mathrm{DID}_{\mathrm{it}}+\beta_{2} \times \mathrm{X}_{\mathrm{it}}+\theta_{1} \times \mathrm{W}_{\mathrm{T}, \mathrm{T}} \times \mathrm{D}_{\mathrm{it}}+\theta_{2} \times \mathrm{W}_{\mathrm{NT}, \mathrm{T}} \times \mathrm{D}_{\mathrm{it}}+\theta_{3} \times \mathrm{W} \times \mathrm{X}_{\mathrm{it}}+\mu_{\mathrm{t}}+\varepsilon_{\mathrm{it}}
$$

where $\mathrm{W}$ represents the first-order adjacency weight matrix, which is widely used in the empirical analysis of air pollution with a strong physical attribute [3], $W_{\mathrm{T}, \mathrm{T}} \times \mathrm{D}_{\text {it }}$ represents the spatial spillover effects on the treated cities, $\theta_{1}$ represents the coefficient of $W_{T, T} \times D_{i t}$, $\mathrm{W}_{\mathrm{NT}, \mathrm{T}} \times \mathrm{D}_{\mathrm{it}}$ represents the spatial spillover effects on the untreated samples neighboring the treated cities, $\theta_{2}$ represents the coefficient of $W_{N T, T} \times D_{i t}, \theta_{3}$ represents the spatial coefficient of $X_{i t}$, and the other parameters are consistent with Equation (1).

Since the dependent variable is discrete (i.e., 1 or 0 ) in panel B, the binary logit model is employed to test the establishment of political promotion tournament in China [13], dividing the research samples into two parts, namely the treated samples and the untreated samples, respectively.

$$
P_{i t}=\alpha_{0}+\alpha_{1} \pi_{\text {it }}+\mu_{\mathrm{t}}+\varepsilon_{\text {it }}
$$


where $P_{i t}$ denotes political promotion at city $i$ in year $t, \alpha_{0}$ denotes the constant term, $\pi_{\text {it }}$ denotes the independent variables including air pollution reduction (DAQI, $\mathrm{DPM}_{2.5}, \mathrm{DPM}_{10}$, $\mathrm{DSO}_{2}, \mathrm{DCO}, \mathrm{DNO}_{2}$, and $\mathrm{DO}_{3}$ incorporating into the equation one by one), economic growth rate (EGR) and the control variables, $\alpha_{1}$ is the coefficients of the independent variables, and the other parameters such as $\gamma_{i}, \mu_{t}$, and $\varepsilon_{i t}$ are also consistent with Equation (1).

\section{Empirical Results and Analysis}

\subsection{Diagnostic Tests of the DID Model}

Before implementing the regression, two diagnostic tests including the parallel trend test [25] and the placebo test $[3,26]$ have been conducted to guarantee the suitability and reliability of the DID model. Taking AQI, for example, the results for those two tests are shown in Figures 2 and 3, respectively. It is clear that the parallel trend test and the placebo test are satisfied, thus the DID model is suitable for this study. Similarly, those two tests are also satisfied for other air pollutants.

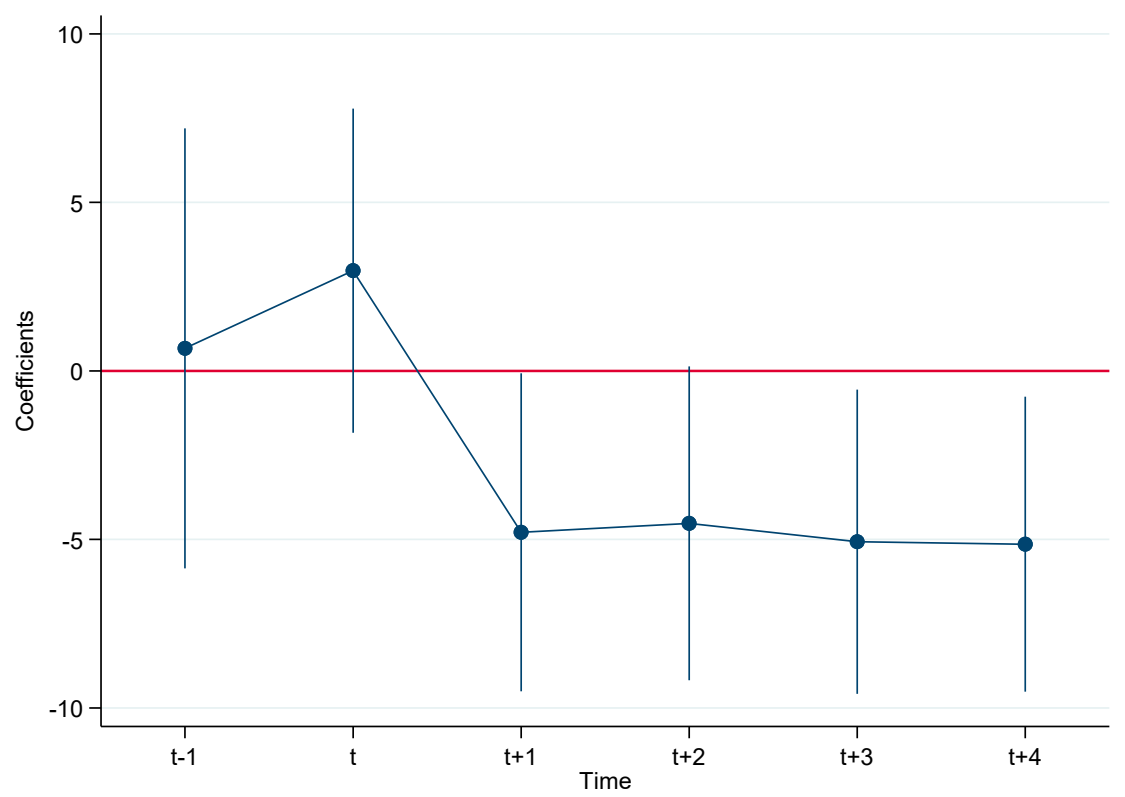

Figure 2. Parallel trend test $(A Q I)$.

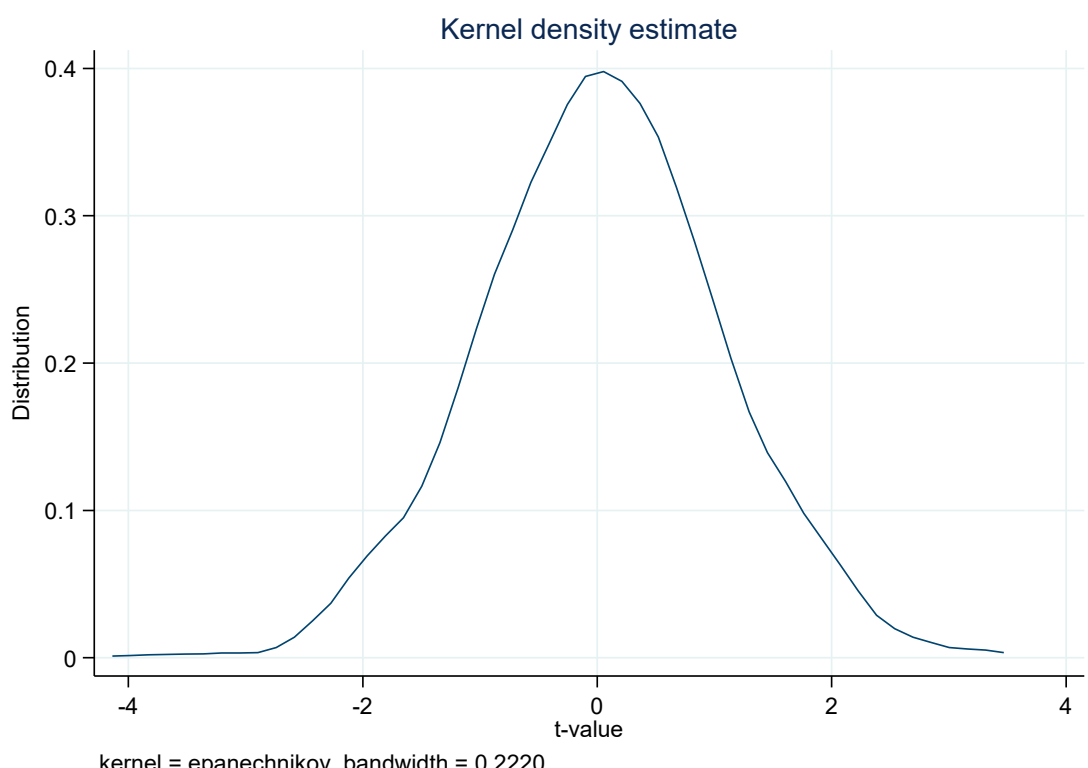

Figure 3. Placebo test $(A Q I)$. 


\subsection{Benchmark Regression Results}

Based on Equation (1), this study has investigated the effects of ECDZ on the seven indicators of air pollution including $\mathrm{AQI}, \mathrm{PM}_{2.5}, \mathrm{PM}_{10}, \mathrm{SO}_{2}, \mathrm{CO}, \mathrm{NO}_{2}$, and $\mathrm{O}_{3}$, and reported the corresponding results in the columns (1)-(7) of Table 2 , respectively.

Table 2. The baseline results based on the DID model.

\begin{tabular}{|c|c|c|c|c|c|c|c|}
\hline \multirow{2}{*}{ Variables } & AQI & $\mathrm{PM}_{2.5}$ & $\mathrm{PM}_{10}$ & $\mathrm{SO}_{2}$ & $\mathrm{CO}$ & $\mathrm{NO}_{2}$ & $\mathrm{O}_{3}$ \\
\hline & (1) & (2) & (3) & (4) & (5) & (6) & (7) \\
\hline DID & $\begin{array}{l}-3.635 \\
(-1.423)\end{array}$ & $\begin{array}{l}-7.131^{* * *} \\
(-3.209)\end{array}$ & $\begin{array}{l}-8.814^{* *} \\
(-2.383)\end{array}$ & $\begin{array}{c}-12.099 * * * \\
(-5.864)\end{array}$ & $\begin{array}{c}0.372 * * * \\
(6.136)\end{array}$ & $\begin{array}{l}-1.772 * \\
(-1.836)\end{array}$ & $\begin{array}{c}10.601 \text { *** } \\
(4.958)\end{array}$ \\
\hline $\operatorname{lnPGDP}$ & $\begin{array}{l}-2.024^{* *} \\
(-2.259)\end{array}$ & $\begin{array}{l}-3.854^{* * *} \\
(-4.942)\end{array}$ & $\begin{array}{l}-5.555^{* * *} \\
(-4.281)\end{array}$ & $\begin{array}{c}-2.235 * * * \\
(-3.087)\end{array}$ & $\begin{array}{l}-0.001 \\
(-0.067)\end{array}$ & $\begin{array}{l}-0.105 \\
(-0.309)\end{array}$ & $\begin{array}{c}3.170 * * * \\
(4.226)\end{array}$ \\
\hline$(\operatorname{lnPGDP})^{\wedge} 2$ & $\begin{array}{c}0.044 \\
(1.252)\end{array}$ & $\begin{array}{c}0.115^{* * *} \\
(3.715)\end{array}$ & $\begin{array}{c}0.157^{* * *} \\
(3.052)\end{array}$ & $\begin{array}{c}0.093^{* * *} \\
(3.228)\end{array}$ & $\begin{array}{l}-0.000 \\
(-0.182)\end{array}$ & $\begin{array}{c}-0.007 \\
(-0.552)\end{array}$ & $\begin{array}{c}-0.128^{* * *} \\
(-4.320)\end{array}$ \\
\hline PD & $\begin{array}{l}-0.001 \\
(-0.600)\end{array}$ & $\begin{array}{l}-0.002^{* *} \\
(-2.038)\end{array}$ & $\begin{array}{l}-0.003^{* *} \\
(-2.383)\end{array}$ & $\begin{array}{l}-0.002^{* * *} \\
(-2.816)\end{array}$ & $\begin{array}{c}-0.000 * * * \\
(-2.699)\end{array}$ & $\begin{array}{l}-0.001 * * \\
(-2.561)\end{array}$ & $\begin{array}{l}0.002 * * \\
(2.233)\end{array}$ \\
\hline SI & $\begin{array}{c}-0.344^{* * *} \\
(-3.209)\end{array}$ & $\begin{array}{c}-0.255^{* * *} \\
(-2.733)\end{array}$ & $\begin{array}{l}-0.452^{* * *} \\
(-2.906)\end{array}$ & $\begin{array}{l}-0.172 * * \\
(-1.979)\end{array}$ & $\begin{array}{c}-0.009 * * * \\
(-3.672)\end{array}$ & $\begin{array}{l}-0.158^{* * *} \\
(-3.894)\end{array}$ & $\begin{array}{l}-0.208^{* *} \\
(-2.314)\end{array}$ \\
\hline $\mathrm{TI}$ & $\begin{array}{l}-0.918^{* * *} \\
(-10.347)\end{array}$ & $\begin{array}{l}-0.947 * * * \\
(-12.268)\end{array}$ & $\begin{array}{l}-1.676^{* * *} \\
(-13.042)\end{array}$ & $\begin{array}{l}-0.961 * * * \\
(-13.402)\end{array}$ & $\begin{array}{l}-0.012 \text { *** } \\
(-5.690)\end{array}$ & $\begin{array}{l}-0.281^{* * *} \\
(-8.378)\end{array}$ & $\begin{array}{c}0.339 * * * \\
(4.559)\end{array}$ \\
\hline FP & $\begin{array}{l}-0.039 \\
(-0.509)\end{array}$ & $\begin{array}{l}-0.095 \\
(-1.427)\end{array}$ & $\begin{array}{c}-0.052 \\
(-0.466)\end{array}$ & $\begin{array}{l}-0.078 \\
(-1.266)\end{array}$ & $\begin{array}{c}0.005^{* * *} \\
(2.923)\end{array}$ & $\begin{array}{l}-0.026 \\
(-0.912)\end{array}$ & $\begin{array}{c}0.057 \\
(0.895)\end{array}$ \\
\hline Constant & $\begin{array}{c}147.130 * * * \\
(17.769)\end{array}$ & $\begin{array}{c}120.005^{* * * *} \\
(16.654)\end{array}$ & $\begin{array}{c}204.285^{* * *} \\
(17.034)\end{array}$ & $\begin{array}{c}86.848^{* * *} \\
(12.981)\end{array}$ & $\begin{array}{c}1.739 * * * \\
(8.840)\end{array}$ & $\begin{array}{c}52.771 * * * \\
(16.858)\end{array}$ & $\begin{array}{c}65.538^{* * *} \\
(9.452)\end{array}$ \\
\hline Samples & 1680 & 1680 & 1680 & 1680 & 1680 & 1680 & 1680 \\
\hline R-squared & 0.159 & 0.265 & 0.280 & 0.320 & 0.074 & 0.106 & 0.151 \\
\hline
\end{tabular}

Notes: t-statistics in parentheses, ${ }^{* * *} p<0.01,{ }^{* *} p<0.05,{ }^{*} p<0.1$.

As is shown in Table 2, the coefficients of DID in columns (2)-(4) and (6) are significantly negative, which indicates that ECDZ has reduced the annual average concentrations of $\mathrm{PM}_{2.5}, \mathrm{PM}_{10}, \mathrm{SO}_{2}$, and $\mathrm{NO}_{2}$. In addition, the coefficient of DID in column (1) is negative but insignificant, which indicates that the reduction effect of ECDZ on AQI is extremely weak in the statistics. However, the coefficients of DID in columns (5) and (7) are significantly positive, which indicates that ECDZ has increased the annual average concentrations of $\mathrm{CO}$ and $\mathrm{O}_{3}$. Thus, without the consideration of the spatial spillover effect, the effects of $\mathrm{ECDZ}$ on different indicators of air pollution have a clear differentiation; this is because compared with $\mathrm{CO}$ and $\mathrm{O}_{3}$, the other four indicators including $\mathrm{PM}_{2.5}, \mathrm{PM}_{10}, \mathrm{SO}_{2}$, and $\mathrm{NO}_{2}$ directly related to haze pollution, which are more sensitive to the public, and more effort is made to control them. Furthermore, long-term and short-term exposure to ambient ground level $\mathrm{NO}_{2}$ and $\mathrm{O}_{3}$ could play an important role in the phenotypes of cardio-respiratory diseases and inflammatory process in the lungs $[27,28]$, thus the increased $\mathrm{O}_{3}$ and the reduced $\mathrm{NO}_{2}$ highlights the complex and difficulty of air pollution reduction in the process of constructing ecological civilization. Therefore, it is not hard to learn why local cadres tend to cope with the assessment of higher officials passively rather than actively.

\subsection{Spatial Regression Results}

Based on the Equation (2), this study has explored the spatial effects of ECDZ on the seven indicators of air pollution including AQI, $\mathrm{PM}_{2.5}, \mathrm{PM}_{10}, \mathrm{SO}_{2}, \mathrm{CO}, \mathrm{NO}_{2}$, and $\mathrm{O}_{3}$, and reported the spatial regression results in the columns (1)-(7) of Table 3 , respectively.

As is shown in Table 3, the coefficients of DID in columns (1)-(3) are significantly negative, the coefficients of it in columns (4) and (6) are negative but insignificant, while the coefficients of it in columns (5) and (7) are significantly positive, which are basically consistent with the benchmark results in Table 2 when ignoring the significance of the coefficients, implying the former effects of ECDZ on the seven indicators of air pollution are relatively robust in local cities. In addition, the spatial coefficients of $\mathrm{W}_{\mathrm{T}, \mathrm{T}} \mathrm{D}$ in columns (2)-(4), and 
(6) are significantly negative, the spatial coefficient of it in column (1) is negative but insignificant, while the coefficients of it in columns (5) and (7) are significantly positive, which indicates that ECDZ has indirectly reduced the annual average concentrations of $\mathrm{PM}_{2.5}, \mathrm{PM}_{10}, \mathrm{SO}_{2}$, and $\mathrm{NO}_{2}$, and increased the annual average concentrations of $\mathrm{CO}$ and $\mathrm{O}_{3}$ among the treated cities, while the reduction effect of it on AQI among the treated cities is relatively weak. Moreover, the spatial coefficients of $\mathrm{W}_{\mathrm{NT,T}} \mathrm{D}$ in columns (1)-(4), and (6) are significantly negative, while the spatial coefficients of it in columns (5) and (7) are significantly positive, which indicates that ECDZ has indirectly reduced the annual average value of $\mathrm{AQI}$ and the annual average concentrations of $\mathrm{PM}_{2.5}, \mathrm{PM}_{10}, \mathrm{SO}_{2}$, and $\mathrm{NO}_{2}$, and increased the annual average concentrations of $\mathrm{CO}$ and $\mathrm{O}_{3}$ in the untreated cities neighboring the treated cities. Therefore, with the consideration of spatial spillover effects, the impacting trends of ECDZ on the seven indicators of air pollution are basically robust when compared with the benchmark results in Table 2, while the spatial spillover effects of $\mathrm{ECDZ}$ on the pilot and non-pilot cities have been identified precisely, which highlights the importance of superior governance once again.

Table 3. The spatial results based on the SDID model.

\begin{tabular}{|c|c|c|c|c|c|c|c|}
\hline \multirow{2}{*}{ Variables } & AQI & $\mathbf{P M}_{2.5}$ & $\mathrm{PM}_{10}$ & $\mathrm{SO}_{2}$ & $\mathrm{CO}$ & $\mathrm{NO}_{2}$ & $\mathrm{O}_{3}$ \\
\hline & (1) & (2) & (3) & (4) & (5) & (6) & (7) \\
\hline DID & $\begin{array}{l}-6.444^{* *} \\
(-1.966)\end{array}$ & $\begin{array}{l}-6.606^{* *} \\
(-2.373)\end{array}$ & $\begin{array}{l}-9.341^{* *} \\
(-2.020)\end{array}$ & $\begin{array}{c}-3.895 \\
(-1.555)\end{array}$ & $\begin{array}{c}0.344^{* * *} \\
(4.490)\end{array}$ & $\begin{array}{l}-1.445 \\
(-1.158)\end{array}$ & $\begin{array}{c}7.181 * * * \\
(2.648)\end{array}$ \\
\hline $\mathrm{W}_{\mathrm{T}, \mathrm{T}} \mathrm{D}$ & $\begin{array}{l}-7.696 \\
(-0.962)\end{array}$ & $\begin{array}{c}-14.840^{* *} \\
(-2.185)\end{array}$ & $\begin{array}{c}-25.962^{* *} \\
(-2.302)\end{array}$ & $\begin{array}{c}-33.647^{* * * *} \\
(-5.504)\end{array}$ & $\begin{array}{c}0.782^{* * *} \\
(4.178)\end{array}$ & $\begin{array}{l}-5.144^{*} \\
(-1.689)\end{array}$ & $\begin{array}{c}19.311 * * * \\
(2.918)\end{array}$ \\
\hline $\mathrm{W}_{\mathrm{NT}, \mathrm{T}} \mathrm{D}$ & $\begin{array}{c}-27.548^{* * *} \\
(-5.305)\end{array}$ & $\begin{array}{c}-25.617^{* * *} \\
(-5.810)\end{array}$ & $\begin{array}{c}-48.643^{* * *} \\
(-6.643)\end{array}$ & $\begin{array}{c}-15.297^{* * *} \\
(-3.855)\end{array}$ & $\begin{array}{c}1.005^{* * *} \\
(8.273)\end{array}$ & $\begin{array}{c}-6.588^{* * *} \\
(-3.332)\end{array}$ & $\begin{array}{c}20.193^{* * * *} \\
(4.700)\end{array}$ \\
\hline Control & Yes & Yes & Yes & Yes & Yes & Yes & Yes \\
\hline Samples & 1680 & 1680 & 1680 & 1680 & 1680 & 1680 & 1680 \\
\hline R-squared & 0.206 & 0.339 & 0.355 & 0.426 & 0.152 & 0.143 & 0.218 \\
\hline
\end{tabular}

Notes: z-statistics in parentheses, ${ }^{* * *} p<0.01,{ }^{* *} p<0.05,{ }^{*} p<0.1$.

\subsection{Test on the Political Promotion Tournament in China}

The effects of ECDZ on air pollution have been verified by adopting the DID and SDID models, while the establishment of the political promotion tournament in China has not been identified, which still needs an empirical test. Based on Equation (3), this study has investigated the effects of economic growth rate and air pollution reduction on political promotion in the treated samples and the untreated samples, and reported the results in Table 4.

As shown in Table 4, the coefficients of EGR are insignificantly positive in columns (1), (3), (5), (7), (9), (11), and (13), but significantly negative in columns (2), (4), (6), (8), (10), (12), and (14), indicating that economic growth rate has reduced the probability of political promotion in the untreated samples, but has a weak trend to promote the probability of political promotion in the treated samples. In addition, except for the significantly positive coefficient of DCO in column (9), all the other thirteen coefficients of air pollution reduction are insignificant in the statistics, that is, only the reduction in $\mathrm{CO}$ increases the probability of political promotion in the treated samples. One possible reason is that the governance of $\mathrm{CO}$ is easier to see the effect in a short time and in turn becomes the key work of local cadres, especially in the areas of ECDZ, which highlights that local cadres tend to cope with the assessment of higher officials passively rather than actively once again. Therefore, although the political promotion tournament in China is not supported in this study, the establishment of the new promotion mechanism based on attaching equal importance to economy and environment still has a long way to go. 
Table 4. The promotion mechanism test.

\begin{tabular}{|c|c|c|c|c|c|c|c|c|c|c|c|c|c|c|}
\hline \multirow{2}{*}{ Variables } & Treated & Untreated & Treated & Untreated & Treated & Untreated & Treated & Untreated & Treated & Untreated & Treated & Untreated & Treated & Untreated \\
\hline & (1) & (2) & (3) & (4) & (5) & (6) & (7) & (8) & (9) & (10) & (11) & (12) & (13) & (14) \\
\hline EGR & $\begin{array}{c}0.015 \\
(0.688)\end{array}$ & $\begin{array}{l}-0.018 * \\
(-1.670)\end{array}$ & $\begin{array}{c}0.015 \\
(0.679)\end{array}$ & $\begin{array}{l}-0.018 * \\
(-1.682)\end{array}$ & $\begin{array}{c}0.014 \\
(0.673)\end{array}$ & $\begin{array}{l}-0.018 * \\
(-1.675)\end{array}$ & $\begin{array}{c}0.015 \\
(0.693)\end{array}$ & $\begin{array}{l}-0.018^{*} \\
(-1.673)\end{array}$ & $\begin{array}{c}0.014 \\
(0.674)\end{array}$ & $\begin{array}{l}-0.018^{*} \\
(-1.709)\end{array}$ & $\begin{array}{c}0.014 \\
(0.674)\end{array}$ & $\begin{array}{l}-0.018 * \\
(-1.698)\end{array}$ & $\begin{array}{c}0.014 \\
(0.655)\end{array}$ & $\begin{array}{l}-0.018 * \\
(-1.680)\end{array}$ \\
\hline DAQI & $\begin{array}{c}-0.003 \\
(-0.413)\end{array}$ & $\begin{array}{c}0.001 \\
(0.240)\end{array}$ & & & & & & & & & & & & \\
\hline $\mathrm{DPM}_{2.5}$ & & & $\begin{array}{c}-0.008 \\
(-0.612)\end{array}$ & $\begin{array}{c}-0.012 \\
(-1.039)\end{array}$ & & & & & & & & & & \\
\hline $\mathrm{DPM}_{10}$ & & & & & $\begin{array}{c}-0.000 \\
(-0.046)\end{array}$ & $\begin{array}{c}0.001 \\
(0.221)\end{array}$ & & & & & & & & \\
\hline $\mathrm{DSO}_{2}$ & & & & & & & $\begin{array}{c}-0.003 \\
(-0.360)\end{array}$ & $\begin{array}{c}0.001 \\
(0.232)\end{array}$ & & & & & & \\
\hline DCO & & & & & & & & & $\begin{array}{l}0.678^{*} \\
(1.784)\end{array}$ & $\begin{array}{c}-0.118 \\
(-0.496)\end{array}$ & & & & \\
\hline $\mathrm{DNO}_{2}$ & & & & & & & & & & & $\begin{array}{c}0.003 \\
(0.143)\end{array}$ & $\begin{array}{c}-0.010 \\
(-0.709)\end{array}$ & & \\
\hline $\mathrm{DO}_{3}$ & & & & & & & & & & & & & $\begin{array}{c}-0.007 \\
(-0.734)\end{array}$ & $\begin{array}{c}-0.001 \\
(-0.138)\end{array}$ \\
\hline Control variables & Yes & Yes & Yes & Yes & Yes & Yes & Yes & Yes & Yes & Yes & Yes & Yes & Yes & Yes \\
\hline Samples & 505 & 895 & 505 & 895 & 505 & 895 & 505 & 895 & 505 & 895 & 505 & 895 & 505 & 895 \\
\hline R-squared & 0.065 & 0.023 & 0.066 & 0.024 & 0.064 & 0.023 & 0.065 & 0.023 & 0.070 & 0.023 & 0.064 & 0.023 & 0.065 & 0.023 \\
\hline
\end{tabular}




\section{Conclusions, Policy Implications, and Research Prospects}

\subsection{Conclusions}

Based on the panel data of 280 Chinese cities from 2014 to 2019, this study has explored the effects of ECDZ on air pollution by adopting the DID and SDID models, and tested the establishment of the political promotion tournament in China by investigating the effects of economic growth rate and air pollution reduction on political promotion by adopting the binary logit model. This study draws the conclusions below.

First, except for $\mathrm{CO}$ and $\mathrm{O}_{3}, \mathrm{ECDZ}$ has to some extent reduced air pollution in China, no matter with or without the consideration of spatial spillover effects, which indicates that the effectiveness of ECDZ on reducing air pollution is basically established for the indicators of air pollution, namely, $\mathrm{AQI}, \mathrm{PM}_{2.5}, \mathrm{PM}_{10}, \mathrm{SO}_{2}$, and $\mathrm{NO}_{2}$, while the controls of $\mathrm{CO}$ and $\mathrm{O}_{3}$ have been neglected, which deserves more attention in the future.

Second, except for the direct effects of ECDZ on air pollution, ECDZ has reduced the annual average values of $\mathrm{AQI}$ and the annual average concentrations of $\mathrm{PM}_{2.5}, \mathrm{PM}_{10}, \mathrm{SO}_{2}$, and $\mathrm{NO}_{2}$ among the treated cities and in the untreated cities neighboring the treated cities, but increased the annual average concentrations of $\mathrm{CO}$ and $\mathrm{O}_{3}$ among the treated cities and in the untreated cities neighboring the treated cities, which highlights the robustness of the impacting trend.

Third, although the political promotion tournament in China is not supported, the effectiveness of ECDZ has been to some extent proved. In particular, the governance of $\mathrm{CO}$ has indeed increased the possibility of political promotion in the treated cities. One possible reason is that the governance of $\mathrm{CO}$ is easier to see the effects of in the short-term and in turn becomes the key work of local cadres, which highlights that local cadres tend to cope with the assessment of higher officials passively rather than actively.

\subsection{Policy Implications}

In order to achieve the win-win of blue sky and economic development and promote the reform of political promotion mechanism simultaneously, several policy implications are provided as follows.

First, due to the differentiation of ECDZ on different indicators of air pollution, the traditional "one-size-fits-all" pattern should be changed, and the governance of them should be adapted to local conditions. In addition, to guarantee the effectiveness of environmental governance institutionally, the evaluation of environmental pollution and protection should be incorporated into the political promotion mechanism.

Second, due to the existence of spatial spillover effects and the collaborative governance problem caused by administrative segmentation, the joint governance of air pollution should be strengthened by adopting a top-level design. In addition, in order to improve the efficiency of cleaner production and lower the emissions of air pollutants simultaneously, a national exchange market of pollutants quota should be established soon.

Third, in order to stimulate the motivation of local cadres and reduce their short-sight behaviors, a lifelong accountability of ecological civilization should be established. In addition, to promote the institutionalization, normalization, and standardization of ECDZ, the institutional joint governance mechanism should cooperate with the joint of the experts in environmental, economic, engineering, and other fields.

\subsection{Research Prospects}

Since this study has offered a novel perspective on identifying the effects of ECDZ on air pollution and the establishment of political promotion tournament in China, several potential directions still need an in-depth exploration. For instance, due to the limited availability of data, the panel data of this study merely include 6 years, which may to some extent soften the persuasiveness. In addition, political connections may be incorporated into the research framework to test the establishment of rent-seeking (Kong et al., 2020). 
Therefore, with the increase in the possibility of available samples and indicators, this topic still deserves further investigation.

Author Contributions: H.W. had the initial idea for this study and interpreted the results. Y.G. designed the conceptual framework of the methodology, drafted, and revised the manuscript. J.Z. and X.X. conducted the work of data collection and econometric analysis. Y.F. performed the calculations and analyzed the data. All of the authors have contributed to the writing and finalizing of the paper. All authors have read and agreed to the published version of the manuscript.

Funding: This research was supported by the National Social Science Foundation of China (No. 20BJY094) and the National Natural Science Foundation of China (No. 72088101 and 71810107001).

Institutional Review Board Statement: Not applicable.

Informed Consent Statement: Not applicable.

Data Availability Statement: The data used to support the findings of this study are available from the corresponding author upon request.

Acknowledgments: We would especially like to thank the experts who participated in the improvement of this study. Any remaining errors are the responsibility of the authors.

Conflicts of Interest: The author declares that they have no conflicts of interest.

\section{References}

1. Feng, Y.Y.; Ning, M.; Lei, Y.; Sun, Y.M.; Liu, W.; Wang, J.N. Defending blue sky in China: Effectiveness of the “Air Pollution Prevention and Control Action Plan" on air quality improvements from 2013 to 2017. J. Environ. Manag. 2019, $252,109603$. [CrossRef]

2. Zheng, S.Q.; Wang, J.H.; Sun, C.; Zhang, X.N.; Kahn, M.E. Air pollution lowers Chinese urbanites' expressed happiness on social media. Nat. Hum. Behav. 2019, 3, 237-243. [CrossRef]

3. Feng, Y.C.; Wang, X.H.; Hu, S.L. Accountability audit of natural resource, air pollution reduction and political promotion in China: Empirical evidence from a quasi-natural experiment. J. Clean. Prod. 2021, 287, 125002. [CrossRef]

4. Hansen, M.H.; Li, H.T.; Svarverud, R. Ecological civilization: Interpreting the Chinese past, projecting the global future. Glob. Environ. Chang. 2018, 53, 195-203. [CrossRef]

5. Kahn, M.E.; Li, P.; Zhao, D.X. Water Pollution Progress at Borders: The Role of Changes in China's Political Promotion Incentives. Am. Econ. J. Econ. Policy 2015, 7, 223-242. [CrossRef]

6. Kong, G.W.; Kong, T.D.; Lu, R.C. Political promotion incentives and within-firm pay gap: Evidence from China. J. Account. Public Policy 2020, 39, 106715. [CrossRef]

7. Zhang, X.H.; Wang, Y.Q.; Qi, Y.; Wu, J.; Liao, W.J.; Shui, W.; Zhang, Y.Z.; Deng, S.H.; Peng, H.; Yu, X.Y.; et al. Evaluating the trends of China's ecological civilization construction using a novel indicator system. J. Clean. Prod. 2016, 133, 910-923. [CrossRef]

8. Gu, Y.F.; Wu, Y.F.; Liu, J.G.; Xu, M.; Zuo, T.Y. Ecological civilization and government administrative system reform in China. Resour. Conserv. Recycl. 2020, 155, 104654. [CrossRef]

9. Zhang, Y.X. "Promotion tournament 2.0": Why local cadres expand health-care provision in China. Governance 2020, 33, 897-914. [CrossRef]

10. Xu, Z.H.; Cao, R.; Hu, X.; Han, W.X.; Wang, Y.X.; Huang, J.; Li, G.X. The Improvement of Air Quality and Associated Mortality during the COVID-19 Lockdown in One Megacity of China: An Empirical Strategy. Int. J. Environ. Res. Public Health 2021, 18, 8702. [CrossRef]

11. Fang, W.; Xiao, M.; Shuo, C. Making Reform Work: Evidence from a Quasi-natural Experiment in Rural China. China Int. J. 2021, 19, 25-46.

12. Chagas, A.L.S.; Azzoni, C.R.; Almeida, A.N. A spatial difference-in-differences analysis of the impact of sugarcane production on respiratory diseases. Reg. Sci. Urban Econ. 2016, 59, 24-36. [CrossRef]

13. Afghari, A.P.; Hezaveh, A.M.; Haque, M.M.; Cherry, C. A home-based approach to understanding seatbelt use in single-occupant vehicles in Tennessee: Application of a latent class binary logit model. Accid. Anal. Prev. 2020, 146, 105743. [CrossRef]

14. Zhou, C.H.; Zhang, X.M. Measuring the Efficiency of Fiscal Policies for Environmental Pollution Control and the Spatial Effect of Fiscal Decentralization in China. Int. J. Environ. Res. Public Health 2020, 17, 8974. [CrossRef]

15. Guo, S.F.; Wen, L.D.; Wu, Y.R.; Yue, X.H.; Fan, G.L. Fiscal Decentralization and Local Environmental Pollution in China. Int. J. Environ. Res. Public Health 2020, 17, 8661. [CrossRef]

16. Pu, Z.N.; Fu, J.S. Economic growth, environmental sustainability and China mayors' promotion. J. Clean. Prod. 2018, 172, 454-465. [CrossRef]

17. Yang, L.; Zhang, J.H.; Zhang, Y.F. Environmental Regulations and Corporate Green Innovation in China: The Role of City Leaders' Promotion Pressure. Int. J. Environ. Res. Public Health 2021, 18, 7774. [CrossRef] 
18. Li, G.; Yuan, Y.; Zhang, M.H.; Zhao, X.; Ji, L. Key Technical Contents of the China VI Emission Standards for Diesel Fuelled Heavy-Duty Vehicles New stringent emissions legislation aims to 'win the blue sky defence war' in China. Johns. Matthey Technol. 2019, 63, 21-30. [CrossRef]

19. Tian, P.; Wu, H.Q.; Yang, T.T.; Jiang, F.L.; Zhang, W.J.; Zhu, Z.L.; Yue, Q.M.; Liu, M.X.; Xu, X.Y. Evaluation of urban water ecological civilization: A case study of three urban agglomerations in the Yangtze River Economic Belt, China. Ecol. Indic. 2021, 123, 107351. [CrossRef]

20. Meng, F.X.; Guo, J.L.; Guo, Z.Q.; Lee, J.C.K.; Liu, G.Y.; Wang, N. Urban ecological transition: The practice of ecological civilization construction in China. Sci. Total Environ. 2021, 755, 142633. [CrossRef]

21. Jin, Y. Ecological civilization: From conception to practice in China. Clean Technol. Environ. 2008, 10, 111-112. [CrossRef]

22. Wu, M.H.; Liu, Y.H.; Xu, Z.C.; Yan, G.; Ma, M.Y.; Zhou, S.Y.; Qian, Y. Spatio-temporal dynamics of China's ecological civilization progress after implementing national conservation strategy. J. Clean. Prod. 2021, 285, 124886. [CrossRef]

23. Chai, J.X.; Zhang, L.H.; Yang, M.; Nie, Q.Y.; Nie, L. Investigation on the Coupling Coordination Relationship between Electric Power Green Development and Ecological Civilization Construction in China: A Case Study of Beijing. Sustainability 2020, $12,8845$. [CrossRef]

24. Ding, G.; Deng, Y.L.; Lin, S.S. A study on the classification of China's provincial carbon emissions trading policy instruments: Taking Fujian province as an example. Energy Rep. 2019, 5, 1543-1550. [CrossRef]

25. Angrist, J.D.; Pischke, J.S. Parallel worlds: Fixed effects, differences-in-differences, and panel data. In Mostly Harmless Econometrics; Princeton University Press: Princeton, NJ, USA, 2008; pp. 221-248.

26. Chen, P.Y.; Hong, Y.L.; Liu, Y. The Value of Multidimensional Rating Systems: Evidence from a Natural Experiment and Randomized Experiments. Manag. Sci. 2018, 64, 4629-4647. [CrossRef]

27. Jones, J.W. Evaluating changes in ambient ozone and respiratory-related healthcare utilization in the Washington, DC metropolitan area. Environ. Res. 2020, 186, 109603. [CrossRef]

28. Zoran, M.A.; Savastru, R.S.; Savastru, D.M.; Tautan, M.N. Assessing the relationship between ground levels of ozone $\left(\mathrm{O}_{3}\right)$ and nitrogen dioxide $\left(\mathrm{NO}_{2}\right)$ with coronavirus (COVID-19) in Milan, Italy. Sci. Total Environ. 2020, 740, 140005. [CrossRef] 